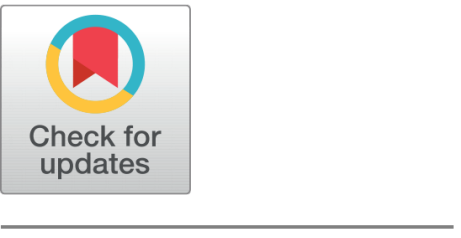

OPEN ACCESS

Received: 02-02-2020

Accepted: 18-03-2020

Published: 20-03-2020

Editor: Dr. Natarajan Gajendran

Citation: Kumar R, Mahar MA, Jumani S, Bhanbro R, Qazi F, Ibupoto M, Soomro F, Memon KH (2020) Biodiversity of Amphibians in Pakistan, causes of their decline and their conservation. Indian Journal of Science and Technology 13(11): 1243-1247. https://doi.org/ 10.17485/IJST/V13i11.149583_2020

*Corresponding author. Khadim H Memon

Department of Zoology, Faculty of Natural Sciences, Shah Abdul Latif University, Khairpur, Sindh, Pakistan khadim.memon@salu.edu.pk

Funding: None

Competing Interests: None

Copyright: @ 2020 Kumar, Mahar, Jumani, Bhanbro, Qazi, Ibupoto, Soomro, Memon. This is an open access article distributed under the terms of the Creative Commons Attribution License, which permits unrestricted use, distribution, and reproduction in any medium, provided the original author and source are credited.

Published By Indian Society for Education and Environment (iSee)

\section{Biodiversity of Amphibians in Pakistan, causes of their decline and their conservation}

\author{
Ranjeet Kumar ${ }^{1}$, Mehtab A Mahar ${ }^{1}$, Sadaf Jumani ${ }^{1}$, Rashida Bhanbro ${ }^{1}$, \\ Faiza Qazi ${ }^{1}$, Mazhar Ibupoto ${ }^{1}$, Fozia Soomro ${ }^{1}$, Khadim H Memon ${ }^{1 *}$ \\ 1 Department of Zoology, Faculty of Natural Sciences, Shah Abdul Latif University, Khairpur, \\ Sindh, Pakistan
}

\section{Abstract}

Objectives: The present study was conducted to review the biodiversity of Amphibians, their decline in population and conservation. Methods/Statistical analysis: This study was done by reviewing the previous papers on biodiversity of Amphibians and available literature on various search engines. Findings: Species of amphibians estimated worldwide reveals 7481 species consisting of three orders, Salientia (Anura), Urodela (Caudata) and Apoda (Gymnophiona). The Salientia contains 6577, Urodela (Caudata) entail 698 species of both land and aquatic inhabitants and Apoda (Gymnophiona) virtually blind and nonmotile animals include 206 species. However, the population of Amphibians is reduced in Pakistan because of dry conditions and is a prominent indicator of climatic change. In Pakistan, the dominating population of Amphibians is Salientia (Anura), consisting of 21 species, 12 genera, and 4 families. Due to anthropogenic activities like the use of pesticides and fertilizers, deforestation, pollution, fragmentation and urbanization affects the amphibians. For conservation and protection, serious initiatives may be mediated to manage the situation. Application/Improvements: The present study will be helpful to conserve the diversity of Amphibians in the region and present findings may be useful in future studies.

Keywords: Amphibia; Pakistan; Decline; conservation; Population

\section{Introduction}

Amphibians are considered to be originated in the period of Devonian but their population dominated in Carboniferous period. This unique group shows a phylogenic link between water and land forms of life. The evolution of Mammals, Birds and Reptiles occurred from amphibians ${ }^{(1)}$. The Amphibians are distributed throughout the globe comprising about 7481 species. The three orders of Amphibians are Salientia (Anura) Urodela (Caudata) and Apoda (Gymnophiona). The Salientia (Anura) encompasses most of the amphibian species about 6577, Urodela (Caudata) includes 698 species of both land and aquatic inhabitants and Apoda (Gymnophiona) 
virtually blind and non-motile animals comprises 206 species ${ }^{(2-5)}$. The total area of Pakistan is $796,096 \mathrm{~km}^{2}$ and the region falls in zoo-geographically into Palearctic and Oriental regions ${ }^{(6)}$. The northern part of Pakistan is at the border of Oriental and Palearctic regions and it is the point where three mountain ranges such as Himalaya, Karakoram, and Hindukush meet. Regardless of these exceptional features amphibian diversity is feebly studied. The climate of Pakistan shows great variation during winter and summer ${ }^{(7)}$. Amphibian population is deprived in Pakistan, and less widespread because of averagely no to little rainfall, nevertheless, Microhylidae, Ranidae, Bufonidae, and Megophryidae are four families, consisting of 24 species are present at the Indus valley in the west bank of the river, runnel of Himalayan North region, water channel and sub-mountainous regions of western Baluchistan ${ }^{(8)}$. The southern area of Pakistan is rich in amphibian population; only one species of amphibians was recorded from the northern areas ${ }^{(9)}$. Four species of a family Bufonidae were observed in different regions of the districts Larkana and Jamshoro ${ }^{(10)}$. Pakistan's amphibians consist of 21 species and 4 families, i.e. Bufonidae, Ranidae, Microhylidae and Megophryidae, initial three were present in Margala Hill National Park ${ }^{(11)}$. Amphibian's body temperature regulation depends upon external sources, their food and energy demand is small because of the low metabolic rate ${ }^{(12)}$. An Amphibian in the diet pyramids have a significant place because their food habits depend on the insects, this in turn controls the population of the insects. These amphibians are used by many predators leading to sifting of nutrients from aquatic to aerial ecosphere ${ }^{(13)}$. Amphibians have pharmaceutical value, Rana tigerina contains antimicrobial protein as well as collagen protein and special lipid components; these components have the capability in amplifying the cell division and differentiation of epidermal and dermal cells to facilitate wound healing naturally. They have other economic, aesthetic and cultural values ${ }^{(14)}$. There is a dearth of information regarding the distribution of most amphibians in most parts of Pakistan because of less consideration by the scientific community ${ }^{(15-17)}$. They have an estimated one-quarter of all classified vertebrates, but their existential threat caused due to hostile conditions because of pollution, habitat loss, deforestation, urbanization and fragmentation ${ }^{(18)}$.

\section{Discussion}

Genus Duttaphrynus (Family Bufonidae) comprises about 5 species. In Pakistan D. stomaticus is widely distributed (Lutkin, 1862 ) in Dasht, the west city of Baluchistan D. olivaceus is mainly distributed (Blanford, 1874) in the Himalayan Range which is home to D. himalayanus (Gunther, 1864). D. hazarensis found in District Hazara, KPK and Punjab. D. melanostictus found in Indus valley (Schneider, 1799). Genus Bufotes (Family Bufonidae) also contains 4 species such as i) Bufotes latastii, found in Laddakh, Shigar Valley (Boulenger, 1882), ii) Bufotes zugmayeri found in Pashin, SE Balochistan (Eislet and Schmidtler, 1973) iii) Bufotes surdus found in Balochistan (Boulenger, 1891) and iv) Bufotes psedooraddei found in Mingora Sawat and KPK, (family Megophryidae) which contains only one species found in Deosai KPK i.e., Scutiger nyingchiensis, (Fei, 1977). In Murree Hills and North Punjab only one species i.e. Microhyla oronata of the genus Microhyla of Microhylidae family is distributed (Dumeril and Bibron, 1841). The Shakarparian Hills and Islamabad are the home to Uperodon systoma species of Uperodon Genus of Microhylidae (Schneider, 1799). The Allopaa hazarensis and Allopaa barmoachensis belongs to the family Dicroglossidae and Genus Allopaa. The Allopaa hazarensis is distributed in Hazara, KPK, Larkana, Jamshoro, Sindh (Dubois and Khan, 1979) and Allopaa barmoachensis found in Barmoach, Azad Kashmir (Khan and Tasnim, 1989). In Quetta, Balochistan, Genus Chrysopaa (family Dicroglossidae) consisting of Chrysopaa Sternosignata is found (Murray, 1885). The Euphlyctis Genus of Dicroglossidae family has two species i.e. Euphlyctis cyanophlyctis (Schneider, 1799) and Euphlyctis hexadactylus. The Euphlyctis cyanophlyctis is found throughout Pakistan and Euphlyctis hexadactylus is found in Khuzdar, Kallat, Balochistan (Lesson, 1834). The single species Fejervarya syhadrensis belongs to genus Fejervarya of Microhylidae family is found in South Punjab and Sindh (Annandale, 1919). The Hoplobatrachus tigerinus found in Punjab and Sindh (Daudin, 1802) belongs to the genus Hoplobatrachus of Microhylidae family. The Nanorana vicina found in Murree, frog is found in Punjab (Stoliczka, 1872) of genus Nanoranaw which belongs to Microhylidae family. The Sphaerotheca strachani is present in Sindh, Karachi, Malir Sindh (Murray, 1884) and Sphaerotheca breviceps found in Sindh, Thatta (Schneider, 1799) are the species of Genus Sphaerotheca which belongs to Microhylidae family Table $1^{(19)}$.

\section{Causes of decline and conservation of Population of amphibians in Pakistan}

Amphibians are inhabited in the parts of Pakistan where water is aplenty. By and large, Pakistan is poor in amphibian fauna because of large parched environmental conditions, habitat loss, amphibian chytrid fungi, and common causes are anthropogenic activities such as deforestation (forest decline to 3.8\%), industrialization (which dumps chemical waste in water making water unsuitable for amphibian), urbanization (increase in human population closes the living and breading water bodies of amphibians for constructing buildings), mechanization of agriculture (ploughing of soil by machines or ox-driven killing the amphibians living in holes and crevices), use of pesticides (kills the amphibian population due to decreased insects in the 
Table 1. Distribution of amphibian fauna in Pakistan

\begin{tabular}{|c|c|c|c|c|}
\hline Specie & Common Name & Distribution & Genus & Family \\
\hline Duttaphrynus stomaticus & Indus toad & Throughout Pakistan & & \multirow{8}{*}{ Bufonidae } \\
\hline Duttaphrynus olivaceus & Olive toad & $\begin{array}{l}\text { Dasht, West Balochis- } \\
\tan \end{array}$ & Duttaphrynus & \\
\hline Duttaphrynus himalayanus & Himalayan Toad & Himalayan Range & \multirow{6}{*}{ Bufotes } & \\
\hline Duttaphrynus hazarensis & $\begin{array}{l}\text { Hazara toad Asian black } \\
\text { spined toad }\end{array}$ & $\begin{array}{l}\text { District Hazara, KPK, } \\
\text { Punjab }\end{array}$ & & \\
\hline Bufotes latastii & Ladakh toad & Laddakh, Shigar Valley & & \\
\hline Bufotes psedudoraddei & Swat toad & Mingora, Swat, KPK & & \\
\hline Bufotes surdus & Iranian toad & Balochistan & & \\
\hline Bufotes zugmayeri & Baloch toad & Pashin, SE Balochistan & & \\
\hline Scutiger nyingchiensis & Tibetan toad & Deosai, KPK & Scutiger & \multirow{3}{*}{$\begin{array}{l}\text { Megophryidae } \\
\text { Microhylidae }\end{array}$} \\
\hline Microhyla oronata & Ant frog & $\begin{array}{l}\text { North Punjab, Murree } \\
\text { Hills }\end{array}$ & Microhyla & \\
\hline Uperodon systoma & Marble frog & $\begin{array}{l}\text { Shakarparian Hills, } \\
\text { Islamabad }\end{array}$ & Uperodon & \\
\hline Allopaa hazarensis & Hazara frog & $\begin{array}{l}\text { Hazara, KPK, Sindh } \\
\text { Larkana Jamshoro }\end{array}$ & Allopaa & \multirow{10}{*}{ Dicroglossidae } \\
\hline Allopaa barmoachensis & Kashmir frog & $\begin{array}{l}\text { Barmoach, Azad Kash- } \\
\text { mir }\end{array}$ & & \\
\hline Chrysopaa sternosignata & Balochistan Karez frog & Quetta, Balochistan & Chrysopaa & \\
\hline Euphlyctis cyanophlyctis & Skittering frog & Throughout Pakistan & \multirow{2}{*}{ Euphlyctis } & \\
\hline Euphlyctis hexadactylus & Green pond frog & $\begin{array}{l}\text { Khuzdar, Kallat, } \\
\text { Balochistan }\end{array}$ & & \\
\hline Fejervarya sayhadrensis & Southern cricket frog & $\begin{array}{l}\text { South Punjab, Sindh } \\
\text { Indus Valley }\end{array}$ & Fejervarya & \\
\hline Hoplobatrachus tigerinus & Bull frog & $\begin{array}{l}\text { Punjab, Sindh Larkana } \\
\text { Jamshoro, Indus valley }\end{array}$ & Hoplobatrachus & \\
\hline Nanorana vicina & Murree frog & Murree, Punjab & Nanorana & \\
\hline Sphaerotheca breviceps & Digging frog & Thattha, Sindh & \multirow{2}{*}{ Sphaerotheca } & \\
\hline Sphaerotheca strachani & Pakistan bull Frog & Malir, Karachi, Sindh & & \\
\hline
\end{tabular}

food-chain) fumigation of granaries, causalities on road ( amphibians are squashed by vehicles when they cross roads to reach their propagation sites), fragmentation by constructing roads and use in scientific experimentation and wide use of Hoplobatrachus tigerinus species as an example for the illustration of vertebrate anatomy decreasing the population of beautiful Indus plains amphibians, and the other concerned phenomena as well ${ }^{(20)}$. Although none of the species of amphibians is taken for edible purpose in any Pakistani culture ${ }^{(21)}$. However, some ecosystems support more Amphibians than birds and mammals, because of the good use of energy ${ }^{(22,23)}$. Not only the scientific community but media also takes into account the decline rate of amphibians causing worry ${ }^{(24,25)}$ as shown in Figure 1.

\section{Recommendations}

1. Look, listen and learn; educate yourself and your family about amphibians.

2. Society's contribution to bringing attentiveness is needed to advance at all levels.

3. Arrange seminar and symposia, domestic and global conferences in educational centers.

4. Plan the conservation activities to revive and protect the population of amphibians.

5. Create an amphibian friendly environment by providing clean water, habitat and the insects that are part of the amphibian food chain.

6. Do not pollute their habitat.

7. Reduce the use of fossil fuels, fertilizers and pesticides.

8. Creation of road free wetlands and the large swampy region as the amphibians dwell all over the plains of Pakistan. 


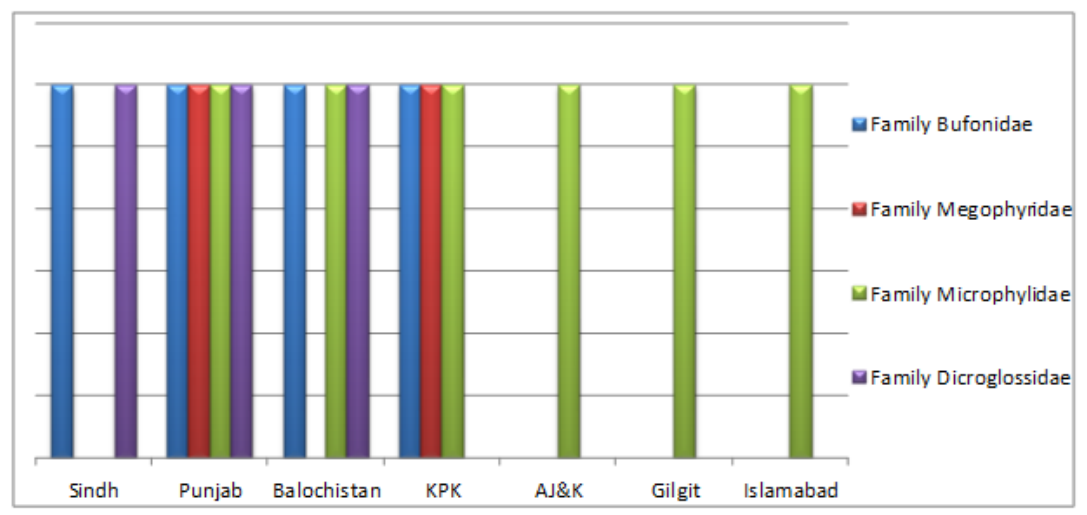

Fig 1. Distribution of Amphibia throughout Pakistan

Where roads currently go across potential breeding sites, construction of underpass or 'frog ways' will considerably reduce amphibian road slaughter.

9. Use legislative regulation to protect amphibian population

10. A comparison study of a single gene and comparative tissue studies of different species of amphibians.

11. Create biopark and Children Park displaying the amphibians in conducive environment.

12. Create genetic pool in conserving the endangered species.

13. Promote virtual Laboratory learning instead of live-specimen dissection in zoology practical classes.

14. Conduct field trips to promote awareness of the amphibian population among student learners at school and college level.

15. Create awareness camps among farmers to impart the role of amphibians as natural pest controlling agents.

\section{Conclusion}

By and large, Pakistan is poorer in amphibian fauna because of increasing parched environmental conditions due to pollution, deforestation, habitat loss, fragmentation and urbanization. Compiling information regarding the amphibian fauna of Pakistan requires special attention. Government should initiate project studies and GIS-based barcoding of the indigenous species. Pakistan has it population dependent on agriculture involving farming and ploughing causing injuries and death of amphibian and reptile fauna.

Due to lack of knowledge, there is a constant threat to amphibian species due to use of fertilizers and in agriculture. So for saving and securing the life of amphibians and reptiles, the effective measures of awareness must be taken by the interest of scientists, government organizations, law enforcement agencies and local communities as well.

\section{Acknowledgment}

We are profoundly grateful to Chairman Department of Zoology Professor Dr. Abdul Manan Shaikh for guidance in the right method for this study and admiration.

\section{References}

1) F D, Grant J, Faivovich RH, Bain A, Haas FB, Haddad O, et al. The Amphibian Tree of Life. Bulletin of the American Museum of Natural History. 2006; (279):1-291.

2) Boulenger GA. 1980. Available from: https://en.wikipedia.org/wiki/The_Fauna_of_British_India,_Including_Ceylon_and_Burma.

3) Ms, British SFO, India. Including Ceylon and Burma Reptile and Amphibia. 1943; (1).

4) Smith WR, of Minto MC. India, Minto, and Morley, 1905-1910. The American Historical Review. 1935; 41(1):147-147. Available from: https://dx.doi.org/ 10.2307/1839379; doi:10.2307/1839379.

5) British MASFO, India. Including Ceylon and Burma Reptile and Amphibia. 1931; (1):85-85.

6) Duellman WE. The pattern of distribution of Amphibian. Baltimore. Johns Hopkin University Press. 1999. Available from: https: //www.google.com/search?q=1.+Duellman+WE.+The+pattern+of+distribution+of+Amphibian.+Johns+Hopkin+University+Press\%2C+Baltimore\% 2C+M.D.+1999.\&oq=1.

7) Khan MS. Herpetology of habitat types of Pakistan. Pakistan Journal of Zoology. 1201; (31):275-289. 
8) Khan MS. Herpetology of Pakistan Part 1-Frog. Nia Zamana Publication. 2011; (1).

9) Crittini AGF, Casiraghi M, Padoa-Schioppa E. New data on Amphibian and Reptiles of the northern area of Pakistan: distribution, genetic variability, and conservation issue. North-Western Journal of Zoology. 2010; (6):1-12.

10) Guchal KS, Shaikh GS, Qadri MY, H. Diversity, morphology, distribution and Population of amphibian fauna in district Jamshoro and Larkana SindhPakistan. Journal of Entomology and Zoology studies. 2015; 3(3):475-479.

11) Mansoor R. An annotated checklist of Amphibians and Reptiles of Margalla Hill National Park. Pakistan Pakistan Journal of Zoology. $2011 ; 43(6): 20-522$.

12) Zug GR, Vitt LJ. Academic Press. 2001. Available from: https://books.google.es/books?id=qdpxsIPm8kkC.

13) Fazey I, Cooper R, Hyde T, Deri A, Hughes L, Bush G, et al. An evaluation of economic and noneconomic techniques for assessing the importance of biodiversity to people in developing countries. Report to the Department for Environment, Food and Rural Affairs. London, UK.. 2008. Available from: https://esanalysis.colmex.mx/Sorted\%20Papers/2012/2012\%20GBR\%20-Biodiv\%20Econ\%202.pdf.

14) Sarwar MK, Malik MF, Hussain M, Azam I, Iqbal W, Ashiq U. Distribution and current status of amphibian fauna of Pakistan: A review. Electronic Journal of Biology. 2016; 12(3):243-246.

15) Khan MS. A new toad of genus Bufo from the foot of Siachen Glacier, Baltistan, northeastern Pakistan. Pakistan Journal of Zoology. $1997 ; 29: 43-48$.

16) Anuradha S, Khan MY. Peripapillary subretinal neovascular complex complicating papillitis. Eye. 1999; 13(1):112-113. doi:10.1038/eye.1999.22.

17) Khan MS. Amphibians and Reptiles of Pakistan. Malabar, Florida. Krieger Publishing Company. 2006. Available from: http://muhammadskhan. wildlifeofpakistan.com/publications.htm.

18) Petrov BP. Petrov the herpetofauna (Amphibia and Reptilians) of the Eastern Rhodopes (Bulgaria and Greece). 2004 p. $863-879$.

19) Mk S, Malik MF, Hussain M, Azam I, Iqbal W, Ashiq U. Distribution and current status of amphibian fauna of Pakistan: A review. Electronic Journal of Biology. 2016; 12(3):243-246.

20) Ms, Khan. A Checklist and Key to the Amphibia of Pakistan. Bullerit Chicago Herpetological Society. 2002; 37(9):163-163.

21) Khan MS. The impact of human activities on the status and distribution of amphibians in Pakistan. Hamadryad. 1990; (15).

22) Fh. Pough the advantages of ectotherm for tetrapod. The American Naturalist. 1980; (115):92-112.

23) Wyman RL. Experimental assessment of salamanders as predators of detrital food webs: effects on invertebrates, decomposition and the carbon cycle. Biodiversity and Conservation. 1998; (7):641-650.

24) Gibbons PW, Stangel JW. Savannah River Eco, laboratory. Herpetology Outreach Publication \# 2. In: Proceedings of the partners in amphibians and conservation (PARC) Conference. 1999.

25) Collins JP. Storfer Global amphibian declines: sorting the hypotheses. Diversity and Distributions. 2003; 9:89-98. 